\title{
Editorial
}

\section{Brand management challenges in the next ten years}

How tired are we all of listening to comments, forecasts and predictions for the next Millennium? You may be, like me, possibly close to burn out! However, always acknowledging the religious significance of the date, at the end of the day we are only shifting through a numerical switch, but there is no doubt that people from all corners of the world in which we live have been inspired to think, often creatively, about how our world may change within the next ten plus years.

So, with that as a thought for the moment, what I would like to do is add a little fuel to those thoughts about the world of branding. In recent years we have seen predictions of the 'death' of brands, followed by an incredible rise in prominence and understanding about the power and importance of the brand. We have seen an unprecedented explosion in the scale of communications surrounding us as a result of something called 'the web'. And finally, we wonder what might be the next stage of growth and business involvement for brand management.

As little as five years ago, predictions of the demise of brand management were everywhere. Esteemed and highly respected and capable consulting companies like (then) Coopers \& Lybrand published articles about it, and companies like Phillip Morris contributed to the expectations with events like Black Friday, April 2nd 1993, when $\$ 20$ bn was wiped off their balance sheet following a 50 cent reduction in the price of a pack of Marlboro' cigarettes. Even basic research, like that presented by myself and my partner at the Chartered Institute of Marketing $\mathrm{Na}$ tional Conference in 1994, showing that 80 per cent of all business to business CEOs were not brand aware or trained, probably helped contribute to that same gloomy forecast.

But what happened? Here we are in 1999 with every large consulting company in the world having a very active brand practice, all the major strategic brand/identity companies seem to have as much work as they can handle and every major research programme we look at says that the brand is seen by executives as critical to the future of the company. Image and reputation is key, as Burson Marstellar recently showed that 40 per cent of your company's image and reputation can be dependent upon the personal image of your CEO. InterbrandScheckter in New York released research showing that even in the crazy, fast-moving, product-driven world of technology, the emotional factors (brand) involved in making purchase decisions are now the primary drivers of that decision.

Ernst \& Young have recently published a good piece looking at 'Measures that Matter' in which they examined those areas which senior corporate executives and the investment community consider important. The brand features quite strongly, ranking 13th most important non-financial measure out of a list of 39. Interestingly for me, what came out was that the investment community still don't yet seem to fully understand how brands really work or how many of the other factors which they consider are actually a direct result of, or a significant contributor to, brand strength. That is our problem to fix. 
Another excellent document came from A. T. Kearney called 'The Role of Brands in the Digital Economy'. ${ }^{2}$ This examines what the development of the Internet world means to all of us concerned with effective brand management. Things like the concept of the economic power of networked communities, the hugely more knowledgeable and information-rich consumer, fragmentation in distribution channels and the fact that the cherished and oft quoted 'Place', as one of the four 'P's pillars of marketing, has changed forever.

And what of the future? The primary challenge for business is to find a way to ensure sustained competitive advantage. The way to do that would seem to be through focusing on an almost universal Business Imperative - customer loyalty. What are customers loyal to? Brands!

Companies like Mars, Disney or GE seem to have mastered the art. Others like CocaCola with New Coke, or IBM who became trapped in the 'downsizing-to-save-moneyand-restore-profitability' syndrome, stumbled and then, to their great credit, recovered magnificently. Size, however, is absolutely no protection or guarantee of sustained competitive advantage.

So thoughts for the future are what? Let me suggest just a few items that we, as a brand community, might want to focus on and consider:

The internet world is not going to go away. It will become even more pervasive but, in doing so, it will make the role of the brand that much more important - the challenge of managing it even greater.

The importance of the brand in purchase decisions generally will increase - but our customers will become ever more discerning and demanding of that consistent, positive brand experience aimed directly at them as individuals.

Focus on customers and not competitors. Customer focus needs to be at the very centre of business strategy and not a totem to which executives tip their hats. Mercer Management Consulting in the USA examined a sample of companies from the Fortune 1000 which had suddenly lost 25 per cent or more of their value within a month. They found that 36 per cent, by far the largest single percentage, had failed due to $\mathrm{CEO} /$ Board error in misjudging customer demand, offering inappropriate product or crashing under customer pressure. Three times as many customer issues than competitor issues were at the heart of their situation.

How active a brand custodian is your CEO? A nimble, alert to change CEO who freely champions the brand will be even more critical to success going forward.

The corporate brand is, usually, the single largest intangible asset in the company. Intellectual Asset Management will grow in importance and brand management will become the centre-piece of IAM strategy.

Whatever happens in the future, the one constant which we will have to understand is PEOPLE. All those brand ambassadors who represent our brand from inside and outside our company, will still be the critical component of a successful brand. All those customers who buy our product/service and help our cause by telling others, are the only reason we are in business at all.

We have a tremendously exciting time ahead as brand managers of the future will, more than ever, have to be scientist, business people, marketer, psychologist and anthropologist. The customer will demand it.

Ian Ryder Editorial Board

\section{References}

(1) Blitz, Amy (1997) 'Measures that Matter', Ernst \& Young, Boston, 1617 7251589.

(2) Kearney, A. T. (1998) 'The Role of Brands in the Digital Economy', Marketing and Communications, Chicago, 13126480111. 